\title{
Simple Screening Method for Double-strand DNA Binders Using Hairpin DNA-modified Magnetic Beads
}

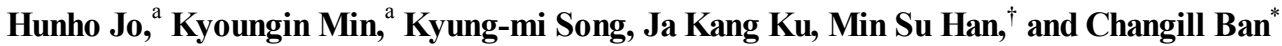 \\ Department of Chemistry, Pohang University of Science and Technology, Gyungbuk 790-784, Korea \\ *E-mail: ciban@postech.ac.kr \\ ${ }^{\dagger}$ Department of Chemistry, Chuang-Ang University, Seoul 156-765, Korea \\ Received October 13, 2010, Accepted November 16, 2010
}

\begin{abstract}
We designed an effective screening method for double strand DNA(dsDNA) binders using DNA-modified magnetic particles. Hairpin DNA was immobilized on the surface of magnetic particle for a simple screening of dsDNA binding materials in a solution containing various compounds. Through several magnetic separation and incubation processes, four DNA-binding materials, DAPI, 9AA, AQ2A, and DNR, were successfully screened from among five candidates. Efficiency of screening was demonstrated by HPLC analysis using a C2/18 reverse-phase column. In addition, their relative binding strengths were verified by measuring the melting temperature $\left(\mathrm{T}_{\mathrm{m}}\right)$. If hairpin DNA sequence is modified for other uses, this magnetic bead-based approach can be applied as a high-throughput screening method for various functional materials such as anti-cancer drugs.
\end{abstract}

Key Words: Screening, dsDNA binder, Magnetic bead, Hairpin DNA, HPLC

\section{Introduction}

Searching for a new material associated with various diseases has long been an issue for the purpose of treatment. In particular, the discovery of effective anti-cancer agents associated with cancer therapy has made this an appealing research field. ${ }^{1-7}$ Among them, dsDNA binding materials are well known as powerful anti-cancer agents. ${ }^{8-11}$ Several dsDNA binders such as daunorubicin (DNR), 9-amido acridine (9AA) and so forth are widely used. ${ }^{12}$ When an anti-cancer agent is being bound to dsDNA, various biological functions such as DNA replication, transcription, and translation are altered. The alterations eventually inhibit the growth of abnormal cells. For example, doxorubicin, a well-known mutagen, has been actively applied as an anti-cancer drug for targeting cancer cells. ${ }^{13-18}$

Methodologies of searching for functional materials, including dsDNA binders, usually involve combinatorial chemistry that finds the most effective compound in a large pool of synthetic chemicals. ${ }^{19-22}$ The most important step in the drug discovery through combinatorial chemistry is the precise selection of candidates having powerful effects on a target disease. Several methods such as mass spectrometry, NMR spectroscopy, and electrochemistry have been utilized for drug screening. ${ }^{23-28}$ However, these techniques need some complementary methods when applied to high-throughput screening. Recently, the colorimetric screening method of dsDNA binders has been developed for this purpose. ${ }^{29-30}$

Separation techniques using magnetic particles have been widely used for high-throughput screening of important materials such as dsDNA binders, DNA-cleaving agents, and DNA aptamers. ${ }^{31-33}$ This method is simple, and does not require a large and expensive machinery system. Since the reaction and purification processes of the screening are carried out just in a single tube, using an external magnet can reduce the amount

${ }^{\mathrm{a}}$ These authors contributed equally to this work.

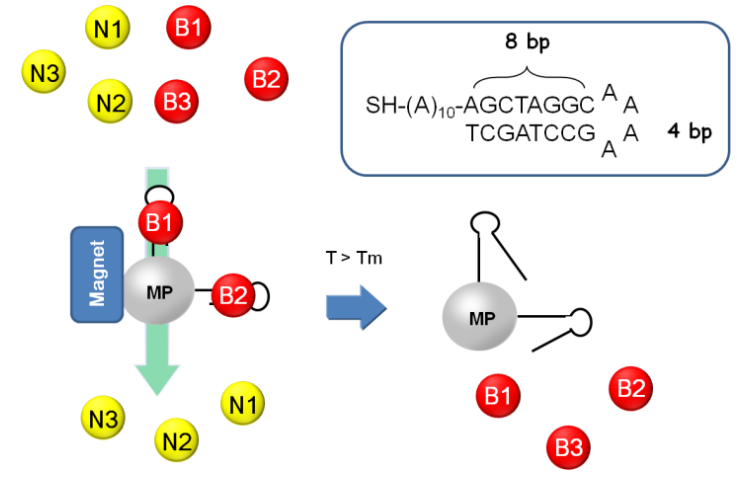

Figure 1. Schematic diagram for screening dsDNA binding materials using hairpin DNA-modified magnetic particles. Red B(n)s are dsDNA binders, and yellow N(n)s represent the non-binding materials for dsDNA. Sequence and structure of hairpin DNA is described in inset.

of unnecessary material and shorten the experimental time. Such advantages can make it possible to simply screen effective target materials from within large pools of synthetic chemicals obtained from combinatorial chemistry.

We designed an effective screening method for dsDNA binders using DNA-modified magnetic particles. As shown in Figure 1, hairpin DNA immobilized on magnetic particles was used to select only dsDNA binding materials, and then candidate materials loaded on the modified magnetic particles could be separated in a short time using the general external magnet. With these processes, only dsDNA binders were sorted out from mixtures, and their relative binding strengths were verified by the melting temperature $\left(\mathrm{T}_{\mathrm{m}}\right)$.

\section{Experimental Section}

Materials. Dynabeads ${ }^{\circledR}$ M-270 Amine and 4',6-diamidino-2phenylindole (DAPI) were purchased from Invitrogen (USA). 
Catechol was bought from Yakuri pure chemicals (Japan). Sulfadimethoxine and DNR were purchased from CalbioChem (USA). Trifluoroacetic acid (TFA) and acetonitrile were purchased from Merck (Germany), and succinimidyl 4-(p-maleimidophenyl) butyrate (SMPB) was purchased from Thermo Scientific (USA). Sulfo-NHS-acetate was obtained from Soltec Ventures (USA). Anthraquinone-2-carboxylic acid (AQ2A), 9AA, and ethyl acetate were purchased from Aldrich (USA), and dimethyl sulfoxide (DMSO) was bought from Daejung chemicals (Korea). Finally, the 5'-thiol-modified hairpin DNA was synthesized from Bionics (Korea).

Activation of Thiol-modified Hairpin DNA. The 5'- thiolmodified hairpin DNA was activated in $0.01 \mathrm{M}$ sodium acetate buffer (pH 5.2) containing 1.0 M ditiothreotol (DTT) at room temperature for $10 \mathrm{~min}$. The thiol groups of the DNA were reduced by this reaction. Excess DTT was removed by the extraction steps using $100 \mu \mathrm{L}$ ethyl acetate more than three times. And then, vacuum evaporator was used to get rid of ethyl acetate in the DNA solution for $5 \mathrm{~min}$. Because the free-sulfhydryl group without DTT was unstable, it was rapidly used to the next step.

Modification of Hairpin DNA on Magnetic Beads. After washing amine-functionalized magnetic particles (Dynabead ${ }^{\circledR}$ M-270 Amine, $10 \mathrm{mg}$ ) with $1 \mathrm{~mL}$ DMSO twice, particles were reacted with $16 \mathrm{mg}$ of SMPB in $1 \mathrm{~mL}$ of DMSO with gentle shaking for $4 \mathrm{~h}$ at dark. After that, magnetic particles were sufficiently washed with DMSO more than five times, and buffer was changed to coupling buffer $(150 \mathrm{mM}$ phosphate buffer $\mathrm{pH}$ 7.0, $200 \mathrm{mM} \mathrm{NaCl})$. Next, reduced hairpin DNA (5' HS-(A) $)_{10}$ AGCTAGGCAAAAGCCTAGCT 3', $5 \mu \mathrm{M}$ ) and SMPB-treated magnetic particles were mixed by constant vortexing for $1 \mathrm{~h}$ in $300 \mu \mathrm{L}$ of the coupling buffer. Magnetic beads were washed with a $1 \mathrm{~mL}$ passivation buffer $(150 \mathrm{mM}$ phosphate buffer $\mathrm{pH}$ $8.0,150 \mathrm{mM} \mathrm{NaCl}$ ) three times, then, the buffer solution was replaced with the passivation buffer for deactivating the remaining SMPB. It was finally reacted with $30 \mathrm{mg}$ of sulfo-NHS acetate through mild shaking in $15 \mathrm{~mL}$ of the passivation buffer for $30 \mathrm{~min}$. These hairpin DNA-modified magnetic particles were finally stored at $4{ }^{\circ} \mathrm{C}$ after sufficient washing with passivation buffer. An external magnet (DynaMag ${ }^{\mathrm{TM}}-2$, Invitrogen) was used for every washing step and buffer exchange procedure. All reactions were carried out at room temperature. ${ }^{34}$

Sample Preparation for HPLC Analysis. Hairpin DNAmodified magnetic particles $(10 \mathrm{mg})$ were pre-incubated with $100 \mu \mathrm{M}$ of catechol in $500 \mu \mathrm{L}$ reaction solution $(0.1 \%$ TFA, 50 $\mathrm{mM} \mathrm{NaCl}$ ) to prevent non-specific binding of materials on the magnetic bead by constant vortexing for $30 \mathrm{~min}$ at $25^{\circ} \mathrm{C}$. Five molecules (each $40 \mu \mathrm{M}$ ) that contained both DNA binders (DAPI, DNR, 9AA, AQ2A) and non-binding material (sulfadimethoxine) were then incubated with $10 \mathrm{mg}$ of hairpin-modified particles in $500 \mu \mathrm{L}$ reaction solution by constant vortexing for $1 \mathrm{~h}$ at $25^{\circ} \mathrm{C}$. After repeating the more than five times washing procedure, gathering of the beads using an external magnet, and resuspending of them into the reaction solution, collected magnetic beads were again resuspended into $500 \mu \mathrm{L}$ of the fresh reaction solution at $30{ }^{\circ} \mathrm{C}$ for $20 \mathrm{~min}$. Then, supernatants, including freely eluted molecules from hairpin DNA, were collected for HPLC analysis. After a single washing step with the

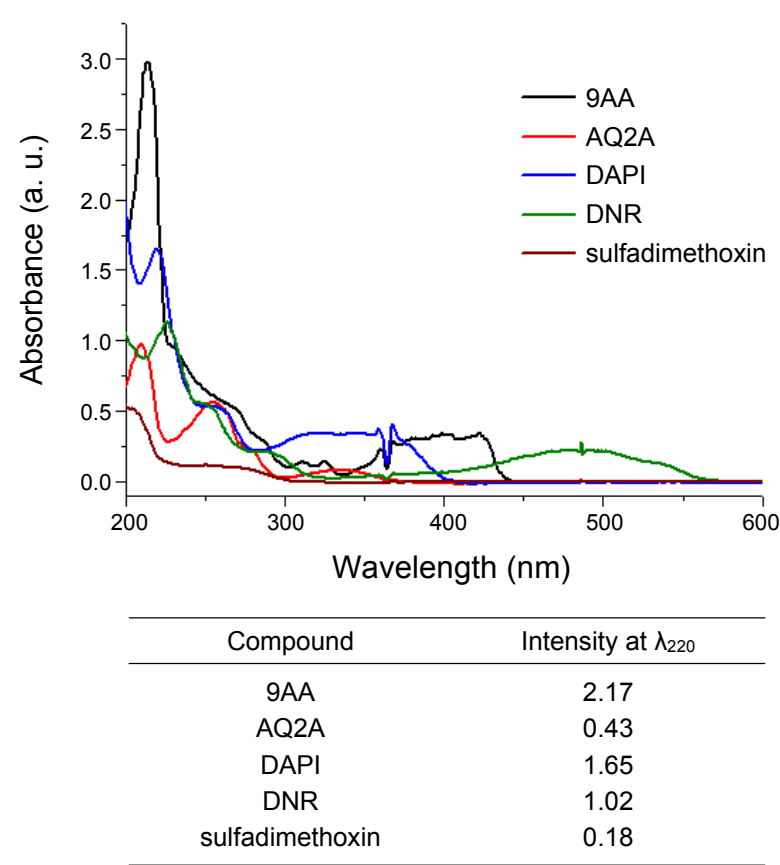

Figure 2. UV scans from $200 \mathrm{~nm}$ to $600 \mathrm{~nm}$ for $5 \mu \mathrm{M}$ of five materials $(400 \mu \mathrm{L}), 9 \mathrm{AA}, \mathrm{AQ} 2 \mathrm{~A}, \mathrm{DAPI}, \mathrm{DNR}$, and sulfadimethoxine. Table: UV intensities at $\lambda_{220}$ for the above compounds, with the wavelength set for the HPLC apparatus for analysis of the injected samples.

reaction solution at $25^{\circ} \mathrm{C}$, the hairpin-modified magnetic beads with the remaining DNA binders were resuspended into $500 \mu \mathrm{L}$ of this solution for the next incubation at the $35^{\circ} \mathrm{C}$ for $20 \mathrm{~min}$. The above procedures were repeated with a $5{ }^{\circ} \mathrm{C}$ interval from $30{ }^{\circ} \mathrm{C}$ to $90{ }^{\circ} \mathrm{C}$.

HPLC Analysis for the Eluted Samples. Preceding the analysis of the samples, maximal absorptions of five materials were verified by UV-vis spectroscopy (Varian). Each absorption spectrum was measured from $200 \mathrm{~nm}$ to $600 \mathrm{~nm}$. Obtained spectra were shown in Figure 2. The materials used in this study naturally had absorbance in the UV region $(220 \mathrm{~nm})$.

The HPLC system consisted of a Spectra Series P200 pump and a UV150 detector. A hydrophobic C2/C18 column ( $\mu$ RPC C2/C18 ST 4.6/100, Amersham Biosciences) was used for separation of the five molecules. A linear gradient of acetonitrile, from 0 to $80 \%$, in $0.1 \%$ TFA and $50 \mathrm{mM} \mathrm{NaCl}$ buffer was set using a $1 \mathrm{~mL} / \mathrm{min}$ flow rate for $50 \mathrm{~min}$, and monitored with a UV-detector at $220 \mathrm{~nm}$.

$\mathbf{T}_{\mathbf{m}}$ Measurement of dsDNA Binders. Hairpin DNA (5' (A) $)_{10}$ AGCTAGGCAAAAGCCTAG CT 3', $1 \mu \mathrm{M}$ ) was used in this experiment. Six samples were made: $1 \mu \mathrm{M}$ Hairpin DNA, $1 \mu \mathrm{M}$ Hairpin DNA with $1 \mu \mathrm{M}$ AQ2A, $1 \mu \mathrm{M}$ Hairpin DNA with $1 \mu \mathrm{M}$ 9AA, $1 \mu \mathrm{M}$ Hairpin DNA with $1 \mu \mathrm{M}$ DNR, $1 \mu \mathrm{M}$ Hairpin DNA with $1 \mu \mathrm{M}$ DAPI, and $1 \mu \mathrm{M}$ Hairpin DNA with $1 \mu \mathrm{M}$ of all four materials. All samples were prepared in $1 \mathrm{mM}$ HEPES buffer ( $\mathrm{pH}$ 7.5). Melting curves were obtained with a UV-visible spectrometer system (VARIAN CARY 100 Conc) and were monitored at $260 \mathrm{~nm}$ for DNA. Four steps were completed to get $\mathrm{T}_{\mathrm{m}}$ information from $\mathrm{UV}$ absorption spectra; At a scan rate of $10{ }^{\circ} \mathrm{C} / \mathrm{min}$ from $15{ }^{\circ} \mathrm{C}$ to $95{ }^{\circ} \mathrm{C}$, at a scan rate of $2{ }^{\circ} \mathrm{C} / \mathrm{min}$ from $95{ }^{\circ} \mathrm{C}$ to $15{ }^{\circ} \mathrm{C}$, at a scan rate of $2{ }^{\circ} \mathrm{C} / \mathrm{min}$ from $15{ }^{\circ} \mathrm{C}$ to 
$95{ }^{\circ} \mathrm{C}$, and at a scan rate of $10{ }^{\circ} \mathrm{C} / \mathrm{min}$ from $95{ }^{\circ} \mathrm{C}$ to $15^{\circ} \mathrm{C}$. The first two steps were for annealing and binding between the hairpin DNA and dsDNA binders. Results of the third step were only used to make $\mathrm{T}_{\mathrm{m}}$ curves.

\section{Results and Discussion}

Preparation of Hairpin DNA-modified Magnetic Beads. For introducing dsDNA onto magnetic beads, hairpin DNA was selected to use only one kind of magnetic particle. While linear DNA case needs the two kinds of magnetic particle for annealing, hairpin DNA case requires only one type of magnetic particle because of the self-formation of dsDNA. The single type of magnetic particle modified by hairpin DNA allows increased efficiency of recycling and greater simplicity of the experimental process, compared with using two kinds of magnetic particles formed by each linear single-strand DNA molecule. In addition to such advantages, it is well known that the binding strength between hairpin DNA and binders is stronger and more stable than duplex or triplex cases. ${ }^{35}$ Thus, hairpin DNA, 5' AGCTA GGC AAAAGCCTAGCT 3' with 5'-thiol modification using (A) 10 linker, was selected for modification on the surface of the magnetic particles (Figure 1).

The stem had eight base pairings, of which the five GC and three AT pairings were relatively even-distributed, and the loop was composed of four adenine nucleotides. This hairpin DNA stem could easily interact with various binding materials, and the short four-adenine loop provided the high stability of hairpin DNA. Since the type of the stem and loop directly affects on the $\mathrm{T}_{\mathrm{m}}$ of DNA, they need to be controlled to produce the proper temperature range of much less than the boiling point of the buffer. The hairpin sequence was optimized using several measurements of $\mathrm{T}_{\mathrm{m}}$ (data not shown). In addition, the $(\mathrm{A})_{10}$ linker was used as a spacer between the hairpin DNA and magnetic particle.

$\mathbf{T}_{\mathbf{m}}$ Measurements of Each Material. We prepared five kinds of materials, DAPI, AQ2A, DNR, 9-AA, and sulfadimethoxine, for sorting out dsDNA binders and analyzing their relative strengths for binding to hairpin DNA. The structural similarity of materials having absorbance in the UV region was the main concern of the selection. In particular, sulfadimethoxine was utilized as a reference for the non-binding material with dsDNA.

When DNA interacts with other materials like dsDNA binders, the melting temperature of DNA is increased in general because of several interactions such as hydrogen bonding, $\pi-\pi$ base stacking, electrostatic interaction, etc. The $T_{m}$ of the same DNA without 5'-thiol modification was measured at $260 \mathrm{~nm}$ using $1 \mu \mathrm{M}$ of DNA and $1 \mu \mathrm{M}$ of each binder in $1 \mathrm{~mL}$ of $1 \mathrm{mM}$ HEPES buffer. The $\mathrm{T}_{\mathrm{m}}$ values were, DNA itself $\left(50.86^{\circ} \mathrm{C}\right)$, DNA with AQ2A $\left(50.88^{\circ} \mathrm{C}\right)$, DNA with 9AA $\left(58.18^{\circ} \mathrm{C}\right)$, DNA with $\operatorname{DNR}\left(68.13{ }^{\circ} \mathrm{C}\right)$, DNA with DAPI $\left(69.93{ }^{\circ} \mathrm{C}\right)$, and DNA with all four binders $\left(74.98^{\circ} \mathrm{C}\right)$. Through the measured $\mathrm{T}_{\mathrm{m}}$ values, it was clear that the binding strengths of the binders to the used hairpin DNA were DAPI $>$ DNR $>$ 9AA $>$ AQ2A (Figure S1 in the Supplementary Material). Based on these results, it could be expected well-separated peaks in the HPLC analysis for the screening.

HPLC Analysis of Eluted Samples. Hairpin DNA was su-

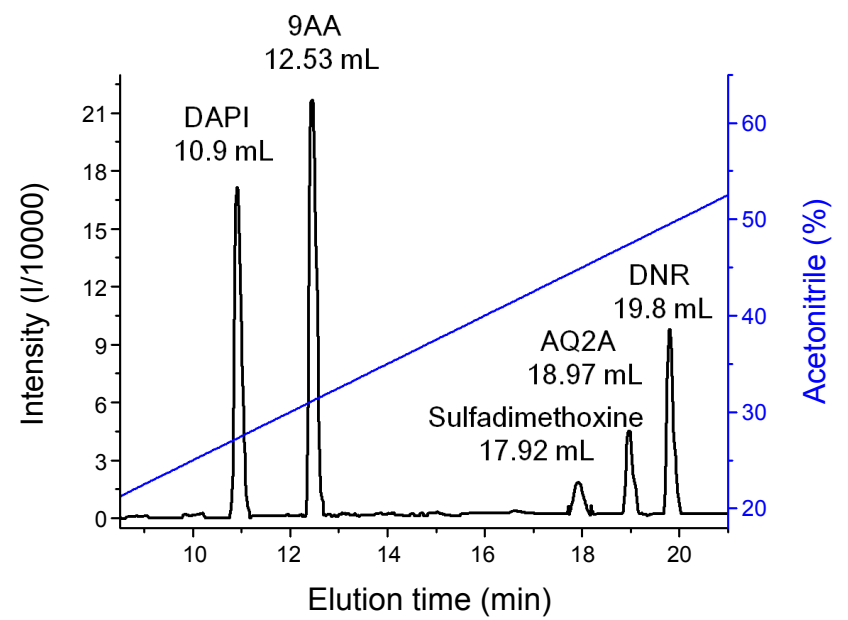

Figure 3. Plot for separation representing elution times of each of the $5 \mu \mathrm{M}$ materials; DAPI $(10.9 \mathrm{~mL}), 9 \mathrm{AA}(12.53 \mathrm{~mL})$, sulfadimethoxine $(17.92 \mathrm{~mL}), \mathrm{AQ} 2 \mathrm{~A}(18.97 \mathrm{~mL})$, and DNR $(19.8 \mathrm{~mL})$ in $0.1 \%$ TFA and $50 \mathrm{mM} \mathrm{NaCl}$ with an acetonitrile gradient using reverse-phase HPLC analysis with a $\mathrm{C} 2 / 18$ column $(1 \mathrm{~mL} / \mathrm{min}$ flow).

ccessfully immobilized on the surface of magnetic particles. The amount of DNA on particles could be measured quantitatively by the difference of absorbance at $\lambda_{260}$ using the remaining solution after the immobilization (data not shown).

Preceding the sorting out of dsDNA binders from these materials, we verified the elution time of each material using a C2/18 reverse-phase HPLC column at $\lambda_{220}$. The mixture containing all five materials was well separated along an acetonitrile gradient, from $0 \%$ to $100 \%$ in $0.1 \%$ TFA and $50 \mathrm{mM} \mathrm{NaCl}$ solution for $50 \mathrm{~min}$ (Figure 3); DAPI (10.9 mL), 9AA (12.53 mL), sulfadimethoxine (17.92 mL), AQ2A (18.97 mL), and DNR $(19.8 \mathrm{~mL})$. These peaks were confirmed by observing the elution time through the separated injection of each material.

Collected supernatants from the above procedures at each temperature were injected into a reverse-phase C2/18 HPLC column to verify the screening effect (Figure S2 in the Supplementary Material). The calculated peak areas for samples at each temperature are listed in Table S1 in the Supplementary Material, and these values are re-plotted with temperature $(\mathrm{T})$ on the $\mathrm{X}$-axis in Figure 4. Each peak was defined by the elution time using the Figure 3 data. As shown by the plots in Figure 4, all of four the DNA binders were well-separated via temperature depending elution. It clearly shows that only these four materials were bound to dsDNA, but not sulfadimethoxine.

In addition to the selectivity, this magnetic bead-based screening method can be applied to an effective separation of dsDNA binders. Among the four binding materials, maximal elutions were observed at $40{ }^{\circ} \mathrm{C}$ for AQ2A, $50{ }^{\circ} \mathrm{C}$ for $9 \mathrm{AA}, 65^{\circ} \mathrm{C}$ for DNR, and $75^{\circ} \mathrm{C}$ for DAPI (Figure 4). Although the AQ2A peak overlaps with the 9AA peak at $45^{\circ} \mathrm{C}$ and the DNR peak overlaps with the DAPI peak at $75^{\circ} \mathrm{C}$ (each less than $15 \%$ ), these can be ignored when compared to overall intensities (Table S1 in the Supplementary Material). Using a specific temperature range, the dsDNA binders can be screened selectively. For example, if modified magnetic beads mixed with several binders are incubated at $45^{\circ} \mathrm{C}$ and then heated to $\sim 60{ }^{\circ} \mathrm{C}$, 9AA can be successfully separated from other binders (Figure 4). Therefore, 


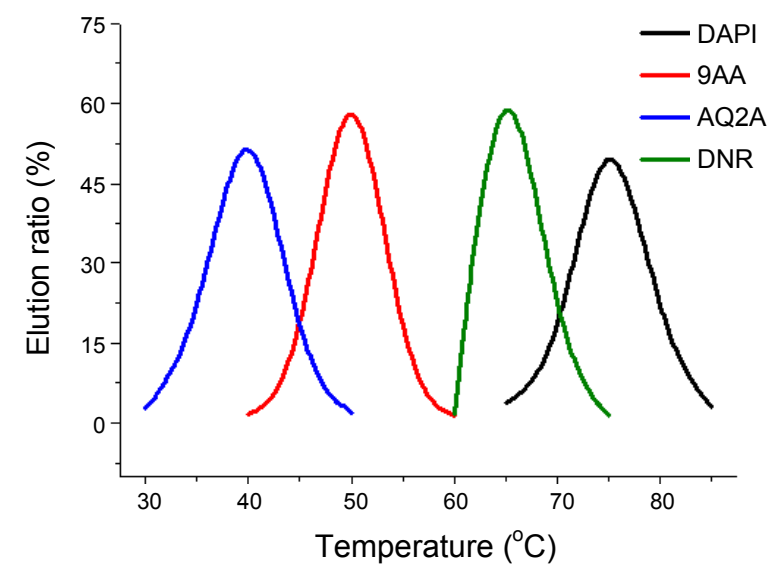

Figure 4. Re-plots for temperature-dependant elution appearances of the magnetic particles with dsDNA binding materials. Intensities of the plots were calculated from elution data from reverse-phase HPLC analysis with a stepwise increase of temperature (Table S1, Figure S2).

our new method using hairpin DNA modified magnetic particles has potential to be used in the screening of several dsDNA binders from many candidates.

This result clearly tells that the relative binding affinities to the hairpin DNA on the magnetic bead are DAPI $>$ DNR $>$ 9AA $>$ AQ2A. This coincides exactly with the order from the measured $T_{m}$ of magnetic particles free hairpin DNA. From this result, DAPI is the strongest dsDNA binder in this library as expected. Thus, this approach based on the magnetic particles simultaneously allows to find the most effective candidates from large libraries, as well as to screen DNA-binding materials. ${ }^{36-38}$

In short, hairpin DNA-modified magnetic particles were used for a simple screening of dsDNA binding materials in a solution containing mixed compounds. We successfully screened four DNA-binding materials, DAPI, 9AA, AQ2A, and DNR, from among five candidates, and then, relative binding strength to hairpin DNA was confirmed by the measurement of $\mathrm{T}_{\mathrm{m}}$. This magnetic bead-based approach can be practically applied as a high-throughput screening method for various functional materials.

Acknowledgments. This work was supported by the Korea Research Foundation (KRF-2008-314-C00218), and the National Research Foundation of Korea (NRF-2010-0019914).

\section{References}

1. Shoemaker, R. H. Nat. Rev. Cancer. 2006, 6, 813-823.

2. O'Connor, P. M.; Jackman, J.; Bae, I.; Myers, T. G.; Fan, S.; Mutoh, M.; Scudiero, D. A.; Monks, A.; Sausville, E. A.; Weinstein, J. N.; Friend, S.; Fornace, A. J. Jr.; Kohn, K. W. Cancer Res. 1997, 57, 4285-4300.

3. Levin, M. A.; Ittman, M.; Melamed, J.; Lepor, H. J. Urol. 2005, 159, 471-475.

4. Yan, Y. K.; Melchart, M.; Habtemariam, A.; Sadler, P. J. Chem. Commun. 2005, 38, 4764-4776.

5. Ohmori, T.; Podack, E. R.; Nishio, K.; Takahashi, M.; Miyahara, Y.; Takeda, Y.; Kubota, N.; Funayama, Y.; Ogasawara, H.; Ohira,
T.; Ohta, S.; Saijo, N. Biochem. Biophys. Res. Commun. 1993, 192, 30-36.

6. Suh, M.-E.; Park, S.-Y.; Lee, H.-J. Bull. Korean Chem. Soc. 2002 , 23, 417-422.

7. Ol'shevskaya, V. A.; Zaytsev, A. V.; Savchenko, A. N.; Shtil, A. A.; Cheong, C. S.; Kalinin, V. N. Bull. Korean Chem. Soc. 2007, 28, 1910-1916.

8. Yang, X. L.; Wang, A. H. J. Pharmacol. Ther. 1999, 83, 181-215.

9. Bailly, C.; Denny, W. A.; Mellor, L. E.; Wakelin, L. P. G.; Waring, M. J. Biochemistry 1992, 31, 3514-3524.

10. Richards, A. D.; Rodgers, A. Chem. Soc. Rev. 2007, 36, 471-483.

11. Hamy, F.; Albrecht, G.; Flörsheimer, A.; Bailly, C. Biochem. Biophys. Res. Commun. 2000, 270, 393-399.

12. Olmsted, J., III.; Kearns, D. R. Biochemistry 1977, 16, 3647-3654.

13. Chu, T. C.; Marks, J. W., III.; Lavery, L. A.; Faulkner, S.; Rosenblum, M. G.; Ellington, A. D.; Levy, M. Cancer Res. 2006, 66, 5989-5992.

14. Farokhzad, O. C.; Cheng, J.; Teply, B. A.; Sherifi, I.; Jon, S.; Kantoff, P. W.; Richie, J. P.; Langer, R. Proc. Natl. Acad. Sci. USA 2006, 103, 6315-6320.

15. Ali-Boucetta, H.; Al-Jamal, K. T.; McCarthy, D.; Prato, M.; Bianco, A.; Kostarelos, K. Chem. Commun. 2008, 4, 459-461.

16. Huang, Y. F.; Shangguan, D. H.; Liu, H. P.; Phillips, J. A.; Zhang, X. L.; Chen, Y.; Tan, W. H. ChemBioChem 2009, 10, 862-868.

17. Müller, I.; Jenner, A.; Bruchelt, G.; Niethammer, D.; Halliwell, B. Biochem. Biophys. Res. Commun. 1997, 230, 254-257.

18. Lee, C. J.; Kang, J. S.; Kim, M. S.; Lee, K. P.; Lee, M. S. Bull. Korean Chem. Soc. 2004, 25, 1211-1216.

19. Thompson, L. A.; Ellman, J. A. Chem. Rev. 1996, 96, 555-600.

20. Balkenhohl, F.; von dem Bussche-Hünnefeld, C.; Lansky, A.; Zechel, C. Angew. Chem. 1996, 108, 2436-2487.

21. Boger, D. L.; Fink, B. E.; Hedrick, M. P. J. Am. Chem. Soc. 2000, 122, 6382-6394

22. Nesterenko, V.; Putt, K. S.; Hergenrother, P. J. J. Am. Chem. Soc. 2003, 125, 14672-14673.

23. Hofstadler, S. A.; Griffey, R. H. Chem. Rev. 2001, 101, 377-390.

24. Robinson, H.; Priebe, W.; Chaires, J. B.; Wang, A. H.-J. Biochemistry 1997, 36, 8663-8670.

25. Pasternack, R. F.; Bustamante, C.; Collings, P. J.; Giannetto, A.; Gibbs, E. J. J. Am. Chem. Soc. 1993, 115, 5393-5399.

26. Li, C.-Z.; Liu, Y.; Luong, J. H. T. Anal. Chem. 2005, 77, 478-485.

27. Wyatt, E. E.; Galloway, W. R. J. D.; Thomas, G. L.; Welch, M.; Loiseleur, O.; Plowright, A. T.; Spring, D. R. Chem. Commun. 2008, 40, 4962-4964.

28. Mitchison, T. J. ChemBioChem 2005, 6, 33-39.

29. Han, M. S.; Lytton-Jean, A. K. R.; Mirkin, C. A. J. Am. Chem. Soc. 2006, 128, 4954-4955.

30. Han, M. S.; Lytton-Jean, A. K. R.; Oh, B.-K.; Heo, J.; Mirkin, C. A. Angew. Chem. Int. Ed. 2006, 45, 1807-1810.

31. Safarik, I.; Safarikova, M. BioMag. Res. Tech. 2004, 2, 1-7.

32. Perez, J. M.; O’Loughin, T.; Simeone, F. J.; Weissleder, R.; Josephson, L. J. Am. Chem. Soc. 2002, 124, 2856-2857.

33. Wochner, A.; Cech, B.; Menger, M.; Erdmann, V. A.; Glökler, J. BioTechniques 2007, 43, 343-353.

34. Stoeva, S. I.; Lee, J.-S.; Thaxton, C. S.; Mirkin, C. A. Angew. Chem. Int. Ed. 2006, 45, 3303-3306.

35. Tse, W. C.; Boger, D. L. Acc. Chem. Res. 2004, 37, 61-69.

36. Reha, D.; Kabelác, M.; Ryjácek, F.; Sponer, J.; Sponer, J. E.; Elstner, M.; Suhai, S.; Hobza, P. J. Am. Chem. Soc. 2002, 124, 33663376 .

37. Antonini, I.; Polucci, P.; Jenkins, T. C.; Kelland, L. R.; Menta, E.; Pescalli, N.; Stefanska, B.; Mazerski, J.; Martelli, S. J. Med. Chem. 1997, 40, 3749-3755.

38. Huang, Q.; Fu, W. L. Clin. Chem. Lab. Med. 2005, 43, 841-842. 